Intersections

Canadian Journal of Music

Revue canadienne de musique
Intersections

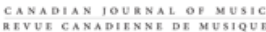

\title{
In and Out of the Sound Studio Introduction
}

\section{Andra McCartney et Ellen Waterman}

Volume 26, numéro 2, 2006

In and Out of the Sound Studio

URI : https://id.erudit.org/iderudit/1013223ar

DOI : https://doi.org/10.7202/1013223ar

Aller au sommaire du numéro

\section{Éditeur(s)}

Canadian University Music Society / Société de musique des universités canadiennes

ISSN

1911-0146 (imprimé)

1918-512X (numérique)

Découvrir la revue

Citer ce document

McCartney, A. \& Waterman, E. (2006). In and Out of the Sound Studio: Introduction. Intersections, 26(2), 3-19. https://doi.org/10.7202/1013223ar

\section{Résumé de l'article}

Dans l'introduction à ce numéro spécial d'Intersections, Andra McCartney et Ellen Waterman présentent les Dedans et Dehors du Studio, un projet de recherche ethnographique inter-universitaire soutenu financièrement par le CRSH du Canada de 2001 à 2005. L'équipe de recherche a étudié les idées et pratiques des artisans sonores canadiens, se penchant particulièrement sur le sujet de la relative invisibilité et inaudibilité des femmes, réfléchissant aux différentes manières dont les technologies et pratiques sonores peuvent être orientées sexuellement. Dans leurs essais, les auteures discutent des relations trouvées entre les termes genre, son et technologie, du point de vue aussi bien terminologique, qu'esthétique, du mentorat, ou encore méthodologique et théorique. Les contributions de McCartney, Diamond, Laplante, Labrosse, Marsh et Bosma sont ici discutées.
Copyright @ Canadian University Music Society / Société de musique des universités canadiennes, 2007
Ce document est protégé par la loi sur le droit d'auteur. L'utilisation des services d'Érudit (y compris la reproduction) est assujettie à sa politique d'utilisation que vous pouvez consulter en ligne.

https://apropos.erudit.org/fr/usagers/politique-dutilisation/ 


\section{INTRODUCTION: IN AND OUT OF THE SOUND STUdio}

\section{Andra McCartney and Ellen Waterman}

In and Out of the Sound Studio is an inter-university ethnographic project, conducted by Dr. Andra McCartney, Concordia University; Dr. Ellen Waterman, University of Guelph; Dr. Beverley Diamond, Memorial University; and Dr. Kip Pegley, Queen's University. ${ }^{1}$ We are studying ideas and practices of contemporary Canadian soundmakers, ${ }^{2}$ aiming to address the relative invisibility and inaudibility of women, and thinking about ways in which sound technologies and practices are gendered. The title of the project refers to the position of women and other marginalized groups, who may gain access to the sound studio, but often feel outside of its discourse; to the material conditions of women's lives, in which familial responsibilities and social conditions can interfere with their ability to stay in the studio; to the contemporary condition of sound technology, in which work is increasingly done outside the studio on a laptop or other digital device; and to the position of this research project, which does work inside and out of the academy.

We interviewed soundmakers from many spheres of technological audio production: radio art, documentary and programming; music performance and recording; film sound recording and design; video game sound design; theatre sound; performance art; museum sound and gallery installation work; and electroacoustic music. The majority of consultants were women. The interviewers are scholars who are also professional soundmakers, including professors and graduate research assistants. We attempted to match research assistants with consultants in a similar area of creative practice, in order to facilitate opportunities for mentoring.

In July 2005, as a result of receiving an Image, Text, Sound and Technology grant from the SSHRC, we presented a conference on the project at Concordia University in Montréal. This event brought together Canadian, American and European scholars, graduate and undergraduate students with sound designers, artists and producers from diverse creative fields. The present volume represents a selection of scholarly articles drawn from the conference and from the

1 The project was funded by the Social Sciences and Humanities Research Council, Le Centre interuniversitaire des arts médiatiques (Hexagram), Concordia University, and the Centre for Music, Media and Place at Memorial University.

2 We use the term soundmakers rather than composers because some practitioners in the study identify as producers, artists or designers rather than as composers. "Soundmaker" riffs off of the Dutch term for creative radio artists, called radiomakers. Plantenga defines a radiomaker as a "prankster, a playful soul." $(2002,82)$ Similarly, soundmaker suggests the freedom to experiment with diverse technologies and practices. 
wider project. In this introduction we want to contextualize our research and take the opportunity to reflect critically on its goals and outcomes.

\section{WOMEN/GENDER}

Throughout our study we have tried to balance our political commitment to the work of women soundmakers with a nuanced theorization of gender. Overwhelmingly, women have been marginalized in fields where creative work in sound and music meets technology. ${ }^{3}$ By focusing on women soundmakers we hope to foster creative networks, to provide opportunities for mentoring, and to suggest the possibility of a multi-valent feminist aesthetics of sound. While most often occupying the social categories "woman" or "man" our consultants and researchers inhabit a number of positions on the spectra of gender and sexuality. Our conference reflected this range by providing opportunities for presentations on gender terrorism, male desire, and the transmutation of gender identities in electroacoustic music.

The idea that gender is a social construction requiring constant performance and circumscribed by discourse is by now well established. ${ }^{4}$ Such performances may be motivated and defined by a wide range of criteria including sexuality, cultural and geographic location, professional aspirations, inherited physical traits, and philosophical, political, and aesthetic commitments. Gendered performances by women and men in sound and technology may include, for example: "the stereotypical woman or man," "the genderless composer," "the macho technologist," and "the rational producer." In interviews, our consultants also discussed their experiences in many other cultural locations, including occupation, class, and race, which sometimes played a larger role in their lives than gender.

Soundmakers often want to forget about gender, being reminded of it too often in the workplace. They want people to pay attention to their work, and the value of sound within their particular realm of production or in the culture more widely, often feeling that sound work is given less attention than visuals or texts. There is concern in the scholarly community that paying attention to gender will essentialize and reify it or generate hierarchies of marginality, as Gayatri Spivak cautions:

Let us, then, for the moment at least, arrest the understandable need to fix and diagnose the identity of the most deserving marginal. Let us also suspend the mood of self-congratulation as saviours of marginality. Let us peer, however blindly, into the constantly shifting and tangling network of the techniques of knowledge and the strategies of power through the question of value. $(1993,61)$

By focusing on techniques of knowledge and strategies of power in the sound studio, though, we want to place gender in the sweet spots, while focusing less on fixed identities than on processes of engendering and evaluation. In the fol-

3 See for example, McCartney, 1998 and Hinkle-Turner, 2003.

4 See for example, Butler, 1990 and Callaghan, 1995. 
lowing sections we address the question of value in three aspects of our research: training and mentoring, aesthetics, and methodology and theory.

\section{Training AND Mentoring}

Desires for technical training, for visible and audible role models, and for mentors in technological sound creation were discussed frequently by participants in this study. ${ }^{5}$ Presently, training takes place in university electroacoustic music and communications sound courses; at technical and art colleges; in workshops at community radio stations and digital arts centres like Studio XX in Montréal and Inter-access in Toronto; and through apprenticeships in live recording situations, recording studios and editing suites.

Participants in the study report a continuing lack of female role models in university electroacoustic music courses, ${ }^{6}$ in which the vast majority of works presented and discussed are by men, with one or two women composers included. Few of the faculty members are women, most of the students in upper year courses are male, and the aesthetics of canonic works are masculinist. Barry Truax provides a historical context for this masculinist construction of the discipline: "electroacoustic music emerged during the post-World War II era when male control of technology, from educational and consumer training through to the engineering profession in general and audio engineering in particular, was the norm" $(2003,117)$. In contrast, the interdisciplinary approach of Communications departments seems to provide a more open environment, with more female faculty, more gender balance among students, and a wider range of aesthetics presented in courses. Participants in the study report that technical college instruction is male dominated while sound courses at art colleges such as NSCAD and OCAD have a closer gender balance in both faculty and student body.

The campus/community radio sector aims to provide access to diverse programming and to give voice to a wide variety of communities, actively striving to eliminate barriers for women and other marginalized groups. Over forty percent of our consultants got their start in campus and community radio. However, although gender parity is sought at the national level, Ellen Waterman's (2006) research reveals that some stations resist gender parity programmes. Some participants spoke of poor or non-existent training, or volunteer technical staff who simply did not show up to assist with production.

The Canadian Society for Independent Radio Production, with the leadership of Victoria Fenner, extended possibilities for training through a series of week-

5 Other studies also emphasize this need. Elizabeth Hinkle-Turner's (2003) large-scale study of United States electroacoustic composers describes the need for mentors and role models. Beverley Diamond's recent survey of women musicians in Newfoundland found that the desire for technological training was one of the most important concerns for women musicians. See her article in this issue.

In 2000, Pauline Oliveros disseminated a survey widely through the internet about the enrollment of women in the composition and electroacoustic areas of music faculties in post-secondary institutions across North America. The informal results indicate that in many schools women make up less than ten percent of the students in electroacoustic and composition programmes, in some cases reduced from a higher percentage in the mid 1980s. 
end workshops for radio producers and an annual summer week-long audio art camp (Full Moon Over Killaloe, or FMOK) focusing on creative sound work. Two sound artists worked intensively with participants in workshops, concerts and presentations that were developed collaboratively. There was gender parity among artists in residence and participants. ${ }^{7}$

Studio XX is a singular model for digital production focusing on women. Their programming includes short workshops, longer courses, "Femmes br@nchées" presentations by artists incorporating creative and technical demonstrations of their work, residencies, festivals, and social events. Because of their importance to the development of digital art by women, we held our introductory conference reception at Studio XX.

In some work situations, such as the live music show circuit and music recording studios, training is done informally, through apprenticeships. In these situations, it seems that active gender discrimination is common. One woman who wished to rent equipment to record a live show at a music store was told that women don't do sound production, and was then forced to lift heavy equipment to prove her strength. ${ }^{8}$ Music recording studios refused to hire her because they claimed she would distract other workers. Another participant reported that her male colleague had to call in sick before a client would allow her to do a mix. ${ }^{9}$ In such situations, without any formal guidelines about gender, it is particularly crucial that women have supportive senior colleagues.

While the support of male colleagues is worthwhile, it is also of great importance that women soundmakers have female role models and mentors at many stages of their lives. Our study indicated that many women who are successful with sound technologies had informal familial mentoring as children-a relative or family friend who provided access to technology and training in its use, whose influence may have worked against pervasive cultural messages that tell boys to tinker and girls to relate (Whitelegg 1992).

Those important mentors in childhood are "second persons," as this concept is developed by feminist epistemologist Lorraine Code (1991). A second person is someone with whom we interact in order to learn the important characteristics of personhood. Thinking of people as second persons is a good antidote to a cultural obsession with individuality, a reminder that knowledge emerges out of dialogue and negotiation.

This idea of second persons guided the methodology of our project. As mentioned earlier, graduate research assistants were asked to interview women in their respective fields of interest. This resulted in interviews of excellent quality, because of common interests and areas of expertise. More importantly, it also resulted in later collaborations. Theatre sound designer Nancy Tobin hired Anna Friz to do promotional work. Lisa Gasior's approach to sound ecology

7 For a history of the Full Moon Audio Art Camps see <http://www.community-media.com/ fullmoon/index.html , and for the Canadian Society for Independent Radio Production see <http:// www.radiosite.ca>.

8 Hinkle-Turner (2003) reports similar sexism at music store rental departments in the U.S.

9 Oddly enough, Boden Sandstrom (2000) notes the use of this same tactic, by one of her male colleagues, of phoning in sick to force a client to consider work by a woman. 
has been influenced by the museum installation work of Diane Lebœuf. Owen Chapman involved some of the project participants in his $\mathrm{PhD}$ dissertation research on sampling practices. ${ }^{10}$

We maintained an emphasis on mentoring throughout the structure of the conference, by eliminating fees for students and providing assistance with travel so that more students could attend. We also reduced fees for artists, to encourage emerging artists to take part. Sessions were included on soundmakers' working practices, along with roundtable discussions, concerts, and theoretical sessions, to provide a range of contexts for conference participants to discuss work and to learn from each other. It is also our intention that the website and resource list generated by this project will provide ongoing role models for emerging soundmakers, as well as educators.

\section{Towards a Feminist Aesthetics of Sound}

The soundmakers attending the conference employed a wide variety of ways of working, reflecting a similarly large range of ideas about what constitutes good or beautiful work. In some cases, they were influenced by the exigencies of a particular medium or situation, while in other cases, participants had developed a conceptual approach that suited their desired work conditions, facilitated a particular kind of experience for audiences, or reflected their ethical beliefs. These very different approaches nevertheless share a concern with respect and dialogue, and a refusal of rigid categories. Similarly, as researchers we have refused the traditional splits among epistemology, ethics, and aesthetics, agreeing with Lorraine Code that these philosophical categories are intertwined. It is this dialogic stance, rather than any one artistic method or aesthetic position, which points us towards a feminist aesthetics of sound.

Michelle Frey, who designs sound for video games, and Diane Lebœuf, a museum exhibit sound designer, might appear on the surface to be working in very different areas-one working within the tight memory constraints of video game consoles, played at home by one or two individuals at a time, while the other is designing for large museum spaces inhabited by many exhibits and people simultaneously. Yet there are some striking similarities in their ways of working. Both speak of needing to take a non-linear approach. In a museum exhibit, a visitor can enter or exit at any time, so the piece must be conceptualized without a fixed beginning or end. Similarly, in video games, a player can stop, start or change direction at any point, so the sound design must accommodate those actions. Both are concerned with creating an immersive experience for their audience. For Michelle Frey (2005), this translates to an emphasis on "texture, tone and space," aspects of sound work that resonate with Lebœuf's description of long, textural loops that transport visitors from one area to another

10 Research assistants for In and Out of the Sound Studio have published their results in a variety of venues, including Musicworks, and .DPI: The Studio XX Electronic Review <http://dpi.studioxx. org $>$. See the resource list published in this volume for citations. Graduate students have also been actively involved in conference presentations; for example, Gasior and Chapman co-presented a panel with McCartney at the 2005 IASPM Canada conference on Auditing Approaches to Studio Control. 
(McCartney and Gasior, 2004). Lebœuf and Frey both refer to the importance of creative foley work; for instance, recording chainsaws on the beach to create car engine sounds (Frey), or taking metal sheets into a bathroom to make the sounds of water in a metal shower at Grosse Ile (Lebœuf). Their aesthetic is listener-focused, spatially oriented, and non-linear.

Beth Curry and Katharine Binns, two University of Regina undergraduate students who presented a sound/film project, discussed their method of working together as "isolated collaboration." Curry stated that:

The most important aspect of the project to me is the way that our method allowed us to deal with and challenge the concept of authorship. Moreover, testing and extending traditional theories of ownership creates an opportunity for subversion of patriarchal values. Working in isolated collaboration enabled us to grow personal connections with the art in addition to fueling our individual desires to immerse ourselves in the project; it also displaced emphasis from either the visuals or the sound. (2005, n.p.)

This approach, in which the makers work in isolation and then come together to unite their work, allowed each of the two makers to be neither leader nor follower and to pursue independent lines of thought, while also benefiting from the creative connection that they were forming through the work. This approach allows silence for each person to find the still, small voice within, while also maintaining possibilities for dialogue and exchange.

Dialogue is also important in the work of Hildegard Westerkamp, who speaks of soundscape as a language. Because of the resistance of sound recordings, the materiality of the sound that makes it more or less recognizable, or more or less subject to change, she negotiates the processing of sound each time anew. She is constantly being surprised by what each sound will or won't do. She acknowledges the agency of sounds, and this respect shapes the studio processing she undertakes. Even within the isolation of her studio, a conversation is taking place.

In the liner notes to her work Ballade Oral, Kathy Kennedy (2006, n.p.) speaks of micro radio transmission as a way to play with intimacy, to bridge distances even with large groups of people. Her large-scale vocal performance works employ trained and untrained vocalists in busy urban environments, using low-watt radio transmission to connect the performers and provide consistent musical cues across wide spaces. "Sound is territory," she says, an ethical acknowledgement of the power of sound in space. Her intention is to create what she describes as an "aural commons, where everyone is free to express vocally and be heard." Kennedy takes an ironic stance to her role as conductor of this aural commons: "look at the little Napoleon," she says, watching a video of a performance at Place des Arts. Yet as conductor, she clearly intends less to direct than to facilitate.

The work discussed at the conference is diverse: some is spatially oriented, some linear and temporal. It resides in different disciplines: soundscape composition, radio art, sonic interventions, video game sound, and so on. It may emphasize vocal sounds, environmental ambiences, or sonic abstractions. 
Throughout all these soundmakers' works, there is an emphasis on the integration of conversation and silence, on listening to the desires and agency of others while simultaneously seeking to express one's own ethics and intentions.

\section{Methodology and Theory}

Our focus on the intersections among gender, sound and technology has created many opportunities for us to explore new ways of knowing, connecting and communicating. In part this is due to the inherently interdisciplinary nature of the project, which brings together a diverse range of participants whose complex array of methodological tools and theoretical positions echoes Gayatri Spivak's trenchant image of a "shifting and tangling network" $(1993,61)$. A project like this, with its uncomfortable and important focus on gender and its privileged and problematic association with technology, has struggled at times to find ways to fit inside and out of the academy.

We have worked hard to enact a politics of interdisciplinarity and inclusion that goes well beyond crossing borders between the sub-disciplines to be found within academic institutions. Where is knowledge made? Who has the power to speak it? Where is equipment housed? Who has access to it? Which practices are encouraged? Which practices are discouraged or ignored? These are key questions that are integral to our broader inquiry. In this section we explore some of the ways in which In and Out of the Sound Studio has addressed diverse "techniques of knowledge" and scrutinized institutional "strategies of power" (Spivak, 1993, 61).

Acknowledging diverse techniques of knowledge within music and sound means widening our perspective on what constitutes a creative practice. As an arts and humanities field that is fragmented into a number of subdisciplines, the academic field of Music is a model of pluralism that paradoxically inhibits cross-fertilization, both because of entrenched institutional categories (composer, musicologist, ethnomusicologist, theorist, performer etc.) and because each subdiscipline has its own codes and standards. In her call to musicians to "Stop, Look, and Listen" in the face of dizzying changes in sound technologies, electroacoustic composer Mary Simoni suggests that:

We need to develop ways to better understand human perception and the experience of electroacoustic music and intermedia. We need to foster avenues of literary criticism, theoretical analysis, and musicological research that inform composition. In short, composers of electroacoustic music and intermedia should partner with psychoacousticians, theorists, and musicologists if we ever hope to pinpoint an aesthetic sensibility on the infinite continua that entwine contemporary composition. (2006, n.p.)

Simoni's welcome comments do not attempt to reach beyond institutional borders, in which the experts are all to be found within the academy, and it is self-evident that composers are responsible for musical creation. Here, value resides in articulating aesthetics within the subdisciplines of electroacoustic and intermedia composition. 
Looking beyond the academy, we could usefully consider the work of other kinds of practitioners in terms of their creative contributions to the art of sound. When Andra McCartney was asked to list the women artists she was interviewing for In and Out of the Sound Studio, she surprised her questioner by including Shelley Craig-a recording mixer. "Isn't she a technician?" The question comes loaded with an implicit "just"-demarcating a firm boundary line between creator and facilitator. In fact, Shelley Craig is one of only two women film re-recording mixers in North America; her position involves creative improvisation at high speed and entails the final responsibility for the sound mix in a film. The In and Out of the Sound Studio conference included a variety of similarly creative practitioners from non-academic fields. Michelle Frey designs the complex, and rich soundscapes demanded by contemporary video games (the current Xbox comes with 5.1 surround sound). Diane Ballon, who works at a university recording studio and as a production specialist in video, creates poetic radio documentaries that exhibit all the technical skill, formal integrity, and textural interest of an electroacoustic composition. Presenting these creative practitioners alongside electroacoustic and soundscape composers such as Wende Bartley, Hildegard Westerkamp, Marcelle Deschênes, and Barry Truax illustrates the limitations of our current standards of art. The complex and heterogeneous field of sound demands an expanded understanding and definition of both "creativity" and "art."

The above examples of sound professionals do little, however, to address the creative work of a number of our consultants whose access to technology and networks of distribution (and hence their power to speak and be heard) is far more limited. We need to develop strategies that serve to empower such voices. In her case study of an audio art camp "Full Moon Over Killaloe," Ellen Waterman (2006) discovered that women participants (most of whom were involved in campus and community radio) overcame barriers such as limited knowledge of technology, demands of work and family, and a lack of entitlement by developing a number of strategies for "purposeful play." These included creating affinity groups, seeking information from peer communities, focusing on limited and specific projects, self-teaching, and finding ways to insert creative "play" into their work lives.

Victoria Fenner, an independent sound artist who created the FMOK workshop, cited the importance of creating a space where professionals could work on a collegial basis with aspiring sound practitioners.

I still like the idea of cross-fertilization between people, [because] the emphasis here is on doing your own thing. [...] The senior people have something to teach but [...] this is also a time for them to explore; [for example] new types of miking or sitting down with another artist and developing a collaborative project. [.. .] I think, too, that the seasoned veterans...there's nothing like sitting down and talking to someone who's brand new who's going "Oh WOW!", and that is something which is so valuable to those of us who have been in it a long time. ${ }^{11}$

${ }^{11}$ Victoria Fenner, interview with Ellen Waterman, July 2001. 
In Fenner's description, both senior and new sound practitioners benefit from a collegial exchange of ideas. This was facilitated by the informal atmosphere of FMOK, in which everyone (artists in residence, technicians, and students) participated in designing the curriculum. FMOK answered Fenner's felt need for a community of independent radio and audio artists. Her work as a grant writer and facilitator both enabled others and provided the impetus she needed to continue her own creative work. Truly reciprocal community learning models, such as FMOK and Studio XX, articulate ethical strategies that empower the work of soundmakers beyond academic and professional institutions, in part by blurring the boundaries between teacher/student, artist/technician, and expert/beginner.

Spivak invites us to put the question of value at the heart of our intellectual and political inquiry. This leads us to ask questions about the function of our research. Who does it serve? What kinds of relationships does it enable? How can we animate values of respect and reciprocity through our work? Answering these questions requires that we reflect on our original purpose, question our theoretical allegiances and their limitations, and take responsibility for creating community through producing accessible forms of knowledge such as websites, and articles placed strategically in professional journals as well as in scholarly publications.

In and Out of the Sound Studio found its first impetus in Andra McCartney's interviews with women electroacoustic composers (McCartney 1994). Her indepth interviews with Hildegard Westerkamp in the studio allowed her access to the composer's way of working, which in turn guided McCartney not only to analyse Westerkamp's compositions, but to articulate her processes in a way that would provide a useful model for other soundmakers. By publishing her dissertation on-line with the Electronic Music Foundation, she provided free dissemination of the work (McCartney 2000).

Since the inception of In and Out of the Sound Studio in 2001, over 100 similarly revealing interviews, case studies, and analyses have been developed by the team. A core value has been to think "beyond a stereotypical 'woman's way of working' into an exploration of the working processes of a wide variety of female cultural producers of sound, and an understanding of those processes in relation to contemporary thinking on gender and technology" (McCartney $2003,96)$. We have continually had to evaluate and critique our assumptions about numerous analytical and social categories, including: "women," "gender," "musician," "creative practice," and "art." The complexity of soundmakers and gender as both theoretical and material categories forecloses any attempt at homology. Instead, they are best articulated as "situated knowledges" (Haraway, 1991) within "constantly shifting and tangling networks."12

We have analysed sound production and processes with a wide variety of critical tools when theorizing gender and sexuality: feminist theory, queer theory, performance theory, insights from musicology and ethnomusicology, a num-

12 Other studies that recognize the contingency of knowledge may be found in music. See for example Slobin, 1993, Born and Hesmondhalgh, 2000, and Wong, 2004. 
ber of "posts" (-colonial, -structural, -modern), communication theory, media studies, and sociology. Inevitably, theoretical allegiances clash. When presented at the conference, Wende Bartley's Rising Tides of Generations Lost (1994), a work that explores a deep-seated desire to find a woman's voice amid the pain of fragmentation, led to highly charged discussions that pitted Bartley's "universal woman" against the determined anti-essentialism of third-wave feminism. Barry Truax's homoerotic Androgyne mon amour (2001), a sound and video piece for bass player and electroacoustics that explores male desire, highlights the need to think beyond binary gender categories to include other marginalized subjectivities. In fact, for Truax, "Access to electroacoustic technology by women or minority groups will always remain an important issue. However, equally important and perhaps more challenging is what other visions the technology will allow the artists to express" $(2003,123)$.

Linguistic codes may also give rise to new theorizations of gender and sound. Writing in French, electroacoustic composer and theorist Claire Pîché references the confusion between the English word "gender" and its French form "genre," to critique the objectification of technology by analyzing works as belonging to "le genre androïdien" or "le genre humain" (Pîché 2006, n.p.).

In locating avenues for the dissemination of In and Out of the Sound Studio we have been concerned to make information available through scholarly, professional and artistic channels. One object has been to create venues (conferences, workshops, internet, and print) where seemingly unrelated creative processes may be demonstrated and discussed. Some of these, such as presenting video game sound and electroacoustic music together, have been discussed here. We are a bit nervous about the ubiquity of the word "community," which too often describes the boundary lines around a specific ideological, professional, or social group: feminists, queers, composers, producers, students, academics. While we have a clear mandate to study and present the work of women soundmakers, we also wish to contextualize this work within the larger cultural discourses they inhabit. "Tangled networks" of information may appear to be messy, but they are productive and relatively non-hierarchical sites both for autonomous creation and for collaboration.

This special issue of Intersections sits alongside publications in artist-run journals, including a recent issue of EContact (2006, Vol. 8.2) and a series of articles in Musicworks that have more immediate diffusion and impact in the lives of soundmakers. Our website is a resource directed at community radio and student audiences. More than a foothold, we hope that the mp3 jukebox of short features based on the project will provide a series of flashpoints for further dialogue on gender and sound technologies. Short radio documentaries based on the conference presentations will be distributed to campus and community radio stations and university libraries.

\section{DESCRIPTION OF CONTENTS}

Andra McCartney conceived and directed In and Out of the Sound Studio, both as a multi-year project, and as an international conference. In the process, she 
has created a network of soundmakers, scholars, and students who, together, have developed a feminist discourse for understanding the relationships among gender, sound and technology. Her contribution to this volume "Gender, Genre and Electroacoustic Soundmaking Practices," cuts to the heart of issues of identity, language, practice, relationship, and interpretation that emerge again and again in the project.

McCartney begins by locating the politics of gender within the founding genres of electroacoustic music: musique concrète and elektronische Musik. Far from being "neutral" genres, debates on their relative aesthetic value were, from their inception, implicitly gendered: the "human" and "artisanal" connotations of musique concrete vs. the "abstract" and "scientific" connotations of elektronische Musik. McCartney explores this discourse in detail through the foundational (and often oppositional) contributions of Schaeffer, Boulez, Stockhausen, and Eimert.

Beyond these familiar figures, however, lie alternative voices, which have too long been "muted"; for example, Daphne Oram. Drawing on the work of feminist epistemologist, Lorraine Code, McCartney widens the discourse of electroacoustic music to consider a wider range of contributions. Code posits two concepts-empathetic knowledge and ecological thinking-by which we might begin to think about knowledge as always being produced in dialogue with others. ${ }^{13}$ Thus expanded, we may begin to address the creative contributions of a broad range of soundmakers, not only electroacoustic composers, but sound designers, and sound technicians. McCartney explores the use of empathetic knowledge and ecological thinking in the work of Oram, Pauline Oliveros, and several participants of In and Out of the Sound Studio: Hildegard Westerkamp, Wende Bartley, Barry Truax, Kathy Kennedy, Diane Lebœuf, and Shelley Craig.

Beverley Diamond's article on local logics and the gendering of music technology in Newfoundland is based on an assessment of the status of women in music conducted by the Research Centre for the Study of Music, Media and Place for the Women's Policy office of the government of Newfoundland and Labrador. This research highlights the importance of studies on gender and sound technologies for music research since technology issues were indicated as a priority for many women in music involved in the assessment.

Several issues raised by Diamond reflect thematic threads that run through the project as a whole. Lack of visibility and accessibility of resources for women instrumentalists and technologists, barriers raised by the language of technology, and desires for increased and more nuanced technological training were all discussed as challenges that women in music face.

Some strategies were raised that also echo those discussed by other project participants. For instance, Diamond notes that while the number of women training as sound engineers in the province is low, there is a larger number who run their own sound production companies. Pamela Morgan, producer

${ }^{13}$ Code's concept of "second persons" is discussed above in the section "Towards a Feminist Aesthetic of Sound." 
of Amber Records, says that she can choose collaborators who respect her, a positive aspect of the role of producer also discussed by Montréal museum designer Diane Lebœuf. Diamond also describes how women musicians in Newfoundland form interdisciplinary new media networks, a practice also found in Montréal around women's digital media centres such as Studio XX.

Diamond argues that senses of place inflect participants' perceptions of gender issues and their strategies for thriving in music. One case is instrument choice: keyboards are less widely used in Newfoundland to accompany fiddle than other instruments, providing fewer opportunities for women keyboard players. A diffuse and powerful aspect of Newfoundland life is isolation, with simultaneous tendencies toward social cohesion and collaboration. The assessment project itself provided further opportunities for participants to collaborate with each other. At the same time, Diamond's position as a "come-from-away" allowed her to discuss issues and conduct a feminist analysis without the constraint of necessarily representing a Newfoundland and Labrador perspective.

Chantale Laplante's essay is written from the perspective of a practitioner, rather than a scholar of music and gender studies, as with the other articles. Laplante does not articulate specific gender issues in her piece. However, following Diamond's (2000) discussion of gender as enacted, articulated or symbolically projected, we can tease out threads of gender issues in Laplante's discussion of a significant period of change in her approach to composition. Diamond makes a distinction between gender issues that are articulated, "those that consultants identified as being related to gender" (2000: 107), those that are enacted, "If ... a consultant simply described male ... players without drawing attention to the gender specificity implied by the description, the gender issue was considered to have been enacted" (2000: 107), and those that are symbolically projected, "the gendering of implicit values, styles or even "genres" of discourse" (2000: 108).

The period of change in Chantale Laplante's working life took place in the context of a compositional residency, which she notes gave her the privilege of time and space for uninterrupted work, as well as economic security for a year. She was inspired by the work of other artists-Cézanne, Francis Bacon, and Morton Feldman. Here she enacts gender, her artistic imaginary populated only by men; however, the aspects of their work that appeal to Laplante symbolically project stereotypically feminine qualities of attentiveness, quiet, intuition, and tactility.

Most striking to us in the context of this publication is Laplante's description of this new approach to listening as a conversation with sound:

Without a preconceived plan, it is a plunge into the unknown. In the company of sound. If one really wishes to listen to it well. If one is ready to listen to it well ... Can the sound itself suggest to me how the piece should unfold, as it happens? (translation by Andra McCartney) ${ }^{14}$

14 Sans plan préconçu, c'est le plongeon dans l'inconnu. En compagnie du son. Si on veut bien l'écouter. Si on est en mesure de lécouter bien ... Le son peut-il me suggérer le déroulement de l'œuvre en train de se faire? 
This attribution of agency to sound, of a conversation with it that makes a preconceived plan useless, is similar to the approaches to composition espoused by other participants in the In and Out of the Sound Studio project, as discussed by McCartney in her article. It is an example of what she would name an empathetic knowledge of sound, an example of gender symbolically projected.

Another excellent example of an empathetic soundmaker may be found in Andrea Jane Cornell's interview with Diane Labrosse, one of the foundational contributors to Québec's distinctive musique actuelle scene. Labrosse works across electroacoustic composition, improvisation, sound installation and in music, theatre, dance, and visual arts contexts. She is also an important enabler of women's music through Supermusique, the production company she cofounded decades ago with Danielle Palardy Roger and Joane Hétu. We wanted to include this interview, because Labrosse models the kind of dialogic engagement with sound and technology found throughout In and Out of the Sound Studio.

Charity Marsh's article takes us in and out of the classroom to consider the potential for alternative pedagogies to resist the often negative identity politics found in the traditional university classroom. If stereotypes about gendered and ethnic identities can be decentred, she argues, then students will be encouraged to engage in positive processes of identification based on shared experiences, rather than preconceived social roles.

With "the radio project," Marsh has developed a flexible group project that moves students out of the classroom and into a community radio station, where they prepare and present a one hour live radio show based on a chosen course theme. The radio project puts students onto common ground, as they encounter the "strange" technologies of radio broadcasting: the sound studio, mixing board, microphone, and "live to air" performance. Students are faced with a broad (and unknowable) audience for their work, which thus takes on a new resonance. Above all, the radio project provides an opportunity for students to bring theory and practice together.

After using the radio project in a number of courses at the University of Regina between 2004 and 2006, Marsh analysed her students' responses to the project. On one hand, she was disappointed to see gendered approaches to technology reinforced in many students' comments: men commonly expressed satisfaction with having a chance to demonstrate their theoretical and technical skills in a public domain, whereas women expressed concern about how their work would be received by the radio audience. ${ }^{15}$ Importantly, Marsh realized the need to work against the preconceptions engendered by the discourse of identity politics when reading and interpreting students' comments. She found that, as students reflected further on the project, both women and men began to speak "differently"; that is, they began to analyse their relationships with each other and with the project itself.

15 Marsh's findings are consistent with recent studies of Community-based Radio by Zeleke (2004) and Waterman (2006). 
One of the very positive effects of Marsh's innovative pedagogy is her mentoring of undergraduate artist/scholars. At the In and Out of the Sound Studio Conference, she presented her work on a panel with four of these students. Not only did this provide excellent professional training for the students, but the insights of these young practitioners were a timely and inspiring contribution to the conference. It is important for senior scholars to remember that social values and theoretical allegiances are not only aligned by gender/ethnicity/class but by age and experience.

Hannah Bosma, an artist/researcher from the University of Amsterdam and NEAR Donemus (a non-profit centre for Dutch contemporary music), was a keynote speaker at the conference. She brings a rich perspective on women's engagements with electroacoustic music, particularly within an interdisciplinary context. Her keynote address, further developed for this special issue of Intersections, is a wide-ranging commentary on the idea of an écriture féminine musicale. To suggest that there might be an identifiable "women's music" is to reference essentialist/anti-essentialist debates that have long occupied feminist theorists, and that date back at least to the mid-1980s among musicologists. Bosma's article surveys this literature and notes its strengths and limitations. She argues that an écriture féminine musicale must be articulated within a postmodern decentralization of authority, while recognizing the need to promote musical works by women, who continue to struggle for recognition within the masculine gendered fields of composition and technology.

Bosma resists the temptation to provide a unified or simple answer to this difficult problem, which has both ethical and aesthetical dimensions. While the strategic essentialism of feminist musicologists such as Marcia Citron (1993) and Renée Cox (1991) may provide a rallying point for women composers, it all too often reinforces the very gender stereotypes it seeks to critique. Instead, Bosma locates numerous positive strategies used by women in electroacoustic music to assert "feminine" or "feminist" values in their music, without defaulting to patriarchal ideals of "womanhood" (mother/nurturer).

One strategy involves resisting the idea of a single creative role, or a single author for a musical work. Bosma discusses works by a number of composer/performers (vocalists, instrumentalists, and often improvisers) who resist a single musical classification. Women who are comfortable occupying multiple and shifting musical identities are also attracted to interdisciplinary work. The flexibility engendered by working across boundaries of media, styles, and genres suggests Bosma, "subverts traditional musical roles and categories that are the foundation of Western musical culture and thus determine the activities of music institutions, intellectual property rights, music education, etc."

One of the problems associated with interdisciplinary work, ironically, is that its very flexibility makes it difficult to categorize. The same quality that contributes to a nuanced écriture féminine musicale, may actually be detrimental to women's careers in electroacoustic music, because they may have difficulty fitting into prescribed funding categories. In response to this problem, Bosma has created a research program to develop and codify best practices for documenting interdisciplinary electroacoustic music. Such documentation preserves not 
only the performative elements of a work (its presentation in a specific context of venue, occasion, time, audience), but it also locates the specific roles of technology (including particular software configurations). The goal is to capture as many vectors as possible in a way that will make the work repeatable by other musicians in other times and places. Women's work is preserved and made accessible to a wider public; when other musicians recreate the work, they contribute their own creative energy to its rearticulation.

In this special issue of Intersections, ${ }^{16}$ we have striven to represent the diversity of voices who contributed to In and Out of the Sound Studio. No one collection of articles can (or should) claim to be comprehensive in covering such broad territory, but we feel that the artists/scholars/teachers/students presented here ably demonstrate the richly complex terrain of sound, gender and technology. Our thanks go out to them for their wonderful contributions, and to all of our colleagues In and Out of the Sound Studio.

\section{REFERENCES}

Bartley, Wende. 1994. Claire-voie, Empreintes Digitales, IMED-9414-CD.

Born, Georgina and David Hesmondhalgh, eds. 2000. Western Music and Its Others. Berkeley and Los Angeles: University of California Press.

Butler, Judith. 1990. Gender Trouble: Feminism and the Subversion of Identity. New York: Routledge.

Callaghan, D. 1995. "The Vicar and Virago: Feminism and the Problem of Identity". In Who Can Speak? Authority and Critical Identity, ed. J. Roof and R. Wiegman, 195-207. Urbana: University of Illinois Press.

Code, Lorraine. 1991. What Can She Know? Feminist Theory and the Construction of Knowledge. Ithaca, NY: Cornell.

Curry, Beth. 2005. "In and Out of the Classroom: Art, Technology, and Pedagogical Practices". Panel presentation at In and Out of the Sound Studio conference, Concordia University, July 28.

Diamond, Beverley. 2000. "The Interpretation of Gender Issues in Musical Life Stories of Prince Edward Islanders". In Music and Gender: Negotiating Shifting Worlds, ed. Pirkko Moisala and Beverley Diamond, 99-139. Urbana: University of Illinois Press.

Frey, Michelle. 2005. "Video Game Sound". Workshop presentation at In and Out of the Sound Studio conference, Concordia University, July 28.

Haraway, Donna. 1991. "Situated Knowledges: the Science Question in Feminism and the Privilege of Partial Perspective." In Simians, Cyborgs and Women: The Reinvention of Nature, 183-202. New York: Routledge.

Hinkle-Turner, Elizabeth. 2003. "Women and Music Technology: Pioneers, Precedents and Issues in the United States". Organised Sound, 8.2: 31-48.

Kennedy, Kathy. 2006. "Ballade Orale". EContact, 8.2, online: <http://cec. concordia.ca/econtact/8_2/Kennedy.html>.

16 We wish to thank Mary Woodside, English editor of Intersections for her steadfast support of this special issue. We also owe a huge debt of thanks to our anonymous readers, for their insightful comments and criticisms, and to our graduate students: Andrea Jane Cornell, Lisa Gasior and Mark Harris. 
McCartney, Andra. 1994. "Creating Worlds for my Music to Exist". MA thesis, York University. Online with University of Toronto Electronic Dissertation Project. <http://www.fis.utoronto.ca/etd/mcca.htm>.

- 1998. "Outside in the Machine: Women Composers of Electroacoustic Music in Canada". In Ghosts in the Machine: Women and Cultural Policy in Canada and Australia, ed. Alison Beale and Annette Van Den Bosch, 181-210. Toronto: Garamond.

-2000. Sounding Places with Hildegard Westerkamp. Monograph published on the Electronic Music Foundation site. <http://www.emf.org/artists/mccartney00/>.

- 2003. "In and Out of the Sound Studio". Organized Sound, Vol. 8.1: 96.

McCartney, Andra and Lisa Gasior. 2004. "From Mixing Boards to Museums:

Diane Lebœuf, Sound Designer". Musicworks, 90 (Fall): 44-51.

Plantenga, Bart. 2002. "Radio and Aural Destabilization \# 6: DJ Memories of Physical Locations and Ethereal Dislocations." In Sonic Geography Imagined and Remembered, ed. Ellen Waterman, 77-91. Manotick and Peterborough, ON: Penumbra Press and the Frost Centre for Canadian Studies and Native Studies.

Sandstrom, Boden. 2000. "Women Mix Engineers and the Power of Sound". In Music and Gender, ed. Pirkko Moisala and Beverley Diamond, 289-307. Urbana: University of Illinois Press.

Simoni, Mary. 2006. "Stop, Look, and Listen". EContact, 8.2, online: <http://cec. concordia.ca/econtact/8_2/simoni.html>.

Slobin, Mark. 1993. Subcultural Sounds, Micro-musics of the West. Hanover: Wesleyan University Press.

Spivak, Gayatri. 1993. Outside in the Teaching Machine. New York: Routledge. Truax, Barry. 2001. Twin Souls, Cambridge Street Publishing, CSR-CD 0102.

- 2003. "Homoeroticism and Electroacoustic Music: Absence and Personal Voice". Organised Sound, 8.2: 117-124.

Waterman, Ellen. 2006. "Purposeful Play: Women Radiomakers in Community-Based Campus Radio in Canada". Atlantis: A Women's Studies Journal, 30.2: 76-87.

Whitelegg, L. 1992. "Girls in Science Education: Of Rice and Fruit Trees". In Inventing Women: Science, Technology, and Gender, ed. G. Kirkup and L. Smith Keller, 178-187. Cambridge, UK: Polity.

Wong, Deborah. 2004. Speak It Louder: Asian Americans Making Music. New York: Routledge.

Zeleke, Elleni Centime. 2004. The Status of Women in Community-based radio in Canada, Prepared for Women's Hands and Voices in collaboration with the National Campus and Community Radio Association. Online: <http:// www.ncra.ca/women/stratPlan.cfm>.

\section{Abstract}

In the introduction to this special issue of Intersections, Andra McCartney and Ellen Waterman reflect on In and Out of the Sound Studio, an inter-university ethnographic 
research project funded by the SSHRC between 2001 and 2005. The research team studied ideas and practices of contemporary Canadian soundmakers, aiming to address the relative invisibility and inaudibility of women, and thinking about ways in which sound technologies and practices are gendered. In their essay, the authors discuss the relationships found among the terms gender, sound, and technology in terms of terminology, aesthetics, mentoring, methodology and theory. Contributions by McCartney, Diamond, Laplante, Labrosse, Marsh, and Bosma are discussed.

\section{RÉSUMÉ}

Dans l'introduction à ce numéro spécial d'Intersections, Andra McCartney et Ellen Waterman présentent les Dedans et Dehors du Studio, un projet de recherche ethnographique inter-universitaire soutenu financièrement par le CRSH du Canada de 2001 à 2005. L'équipe de recherche a étudié les idées et pratiques des artisans sonores canadiens, se penchant particulièrement sur le sujet de la relative invisibilité et inaudibilité des femmes, réfléchissant aux différentes manières dont les technologies et pratiques sonores peuvent être orientées sexuellement. Dans leurs essais, les auteures discutent des relations trouvées entre les termes genre, son et technologie, du point de vue aussi bien terminologique, questhétique, du mentorat, ou encore méthodologique et théorique. Les contributions de McCartney, Diamond, Laplante, Labrosse, Marsh et Bosma sont ici discutées. 